\title{
Effects of Undigested Fraction of Soybean Protein Isolate Hydrolyzed by Microbial Proteases on Serum and Liver Cholesterol Concentrations in Chicks
}

\author{
Hiroshi Ueda and Tomoko KuRoKI \\ Faculty of Agriculture, Ehime University, Matsuyama-shi 790-8566
}

\begin{abstract}
Effects of soybean protein isolate (SPI) and related nitrogen (N) sources on the serum and liver cholesterol concentrations were investigated in chicks. SPI was hydrolyzed by endo- and exo-type microbial proteases for $24 \mathrm{~h}$, and obtained hydrolysate (HYS) was further segmented to digested soluble fraction (DSF) and undigested fraction (UDF) by centrifugation. Seven-day-old chicks were fed experimental diets containing $0.5 \%$ cholesterol for 10 days. In the first experiment, various $\mathrm{N}$ sources including casein were added at the $\mathrm{N}$ level equivalent to $5 \%$ crude protein (CP) to the basal diet containing $20 \%$ CP. SPI and HYS were equally effective in lowering the serum and liver cholesterol concentrations as compared with casein. In contrast, DSF as well as amino acid mixture simulating SPI increased the serum and liver cholesterol concentrations. UDF had the strongest cholesterol-lowering action among the $\mathrm{N}$ sources tested in the first experiment. In the second experiment, $1.2 \%$ UDF added to the basal diet was as effective as $6.0 \%$ SPI in lowering the serum and liver cholesterol concentrations, but $0.6 \%$ UDF had little effect. Since the ratio of DSF and UDF was $9: 1$ on the weight basis, $6.0 \%$ SPI (5.1\% as CP) contained $0.6 \% \mathrm{UDF}(0.3 \%$ as $\mathrm{CP})$. These results indicate that UDF is an important determinant in cholesterol-lowering effect of SPI, although UDF was not able to account entirely for the cholesterol-lowering effect of SPI.
\end{abstract}

(Jpn. Poult. Sci., $37: 19-26,2000)$

Key words : soybean protein, hydrolysate, undigested fraction, cholesterol

The hypocholesterolemic action of soybean protein isolate (SPI) as compared with casein is established in numerous animal models (VAn der Meer and Beynen, 1987) including chicks (UEDA, 1992, 1997). Since both proteins vary in amino acid composition, effect of individual amino acid or ratio of the selected amino acids on the serum cholesterol concentrations has been studied in chicks (UEDA and FuKui, 1996 ; UedA, 1997). However, results were inconclusive as compared with those obtained with rats (Sugano et al., 1984 ; Sugryama et al., $1986 \mathrm{a}, 1986 \mathrm{~b}$ ). Other studies indicated that the cholesterol-lowering activity of SPI was partly lost when SPI was replaced by the amino acid mixture (AA mix) simulating SPI in rabbits (HuFF et al., 1977), rats (NAGATA et al., 1981) and chicks (UEDA and FuJisawA, 1997). Thus, it seems likely that the conformation of SPI plays an important role in determining cholesterol metabolism.

It was reported in rats that undigested fraction (UDF) of SPI hydrolyzed by microbial proteases was more effective than SPI in lowering the serum and liver cholesterol concentrations, whereas digested soluble fraction (DSF) of SPI was rather hypercholesterolemic (Sugano et al., 1988). In their experiment, both fractions were

Received May 25, 1999 Accepted September 27, 1999 
used to provide nitrogen $(\mathrm{N})$ equivalent to $20 \%$ SPI in the diet. However, UDF was reported to account for about $15 \%$ of total hydrolysate (HYS) on the weight basis (SUGANo et al., 1988). Thus, granted that UDF is hypocholesterolemic, there remains possibility that the cholesterol-lowering action of UDF is overestimated when effects of UDF and SPI are compared at the same N levels.

Cholesterol-lowering action of SPI (De SchriJver, 1990) or UDF (Sugano et al., 1988) relative to casein was accompanied by the enhanced fecal steroid excretion. It was also reported in rats that $\mathrm{N}$ content in the distal intestine was positively related with amounts of fecal steroids (De ScHRIJVER, 1990) or with those of unabsorbed cholesterol (Iw Ami et al., 1986). Thus, the digestion rate of protein in the intestine seems to be one of the important factors affecting cholesterol metabolism. At least, definite amounts of undigested protein or residual peptide that interfere with steroid absorption (SUGANO et al., 1988, 1990 ; Iw Aml et al., 1986) must be needed to produce the cholesterol-lowering action of SPI. This indication will be supported by the previous observations (UEDA and FUKUI, 1996 ; UEDA and FuJISAWA, 1997) that the cholesterol-lowering action of SPI in chicks became manifested with the increase in the dietary SPI content.

The gastrointestinal migration of semi-purified diet in chicks determined with chrominum oxide $\left(\mathrm{Cr}_{2} \mathrm{O}_{3}\right)$ was very rapid ; more than $60 \%$ of $\mathrm{Cr}_{2} \mathrm{O}_{3}$ was found in the distal intestine and excreta $4.5 \mathrm{~h}$ after feeding diet (UedA and Shigemizu, 1998). Thus, it is expected that the hydrolysis of SPI prior to ingestion markedly affects its cholesterol -lowering action in chick. Species-dependent response of serum cholesterol to the dietary proteins has been pointed out (VAN der MEER and BEYNEN, 1987). In the present experiment, effects of DSF and UDF prepared from SPI on the serum and liver cholesterol concentrations in chicks were compared in consideration for the ratio of both fractions in the parent protein.

\section{Materials and Methods}

\section{Hydrolysis of protein}

A $10 \%$ solution of SPI (Fujipro E, Fuji Oil Co., Osaka) was hydrolyzed by endo- and exo-type microbial proteases from Bacillus subtilis and Aspergillus oryzae, respectively (Proteases N and A, Amano Pharmaceutical Co., Nagoya). Each enzyme was added at the $1 \%$ level of protein and incubated at $50^{\circ} \mathrm{C}$ without $\mathrm{pH}$ adjustment. After incubation for $24 \mathrm{~h}$, HYS was heated at $80^{\circ} \mathrm{C}$ for $30 \mathrm{~min}$ to inactivate the enzyme. A part of HYS was centrifuged at $10,000 \mathrm{rpm}$ for $10 \mathrm{~min}$ twice to segment DSF and UDF. All digests were freeze-dried. The ratio of DSF and UDF was $9: 1$ on the weight basis. The chemical composition and $\mathrm{N}$ distribution in various $\mathrm{N}$ sources used in the present experiment are given in Table 1.

Diet

The composition of basal diet containing $20 \%$ crude protein (CP) provided by casein (Wako Pure Chemical Ind., Osaka) was as follows (\%); casein 22.68, L-arginine 0.82, L-methionine 0.2, glycine 0.43, mineral mixture 6.52 (UEDA et al., 1995), vitamin mixture 0.1 (UEDA et al., 1995), choline chloride 0.2 , corn oil 3.0 , cholesterol 0.5 , cellulose 3.0 , cornstarch 20.0 , and glucose to bring up to 100.0 . 
Table 1. Chemical composition and nitrogen $(\mathrm{N})$ distribution of $\mathrm{N}$ sources.

\begin{tabular}{|c|c|c|c|c|c|c|c|}
\hline \multirow{2}{*}{$\mathrm{N}$ source ${ }^{1)}$} & \multicolumn{5}{|c|}{ Chemical composition (\%) } & \multicolumn{2}{|c|}{$\begin{array}{l}\mathrm{N} \text { distribution } \\
(\% \text { of } \mathrm{CP})\end{array}$} \\
\hline & Moisture & $\begin{array}{l}\text { Crude } \\
\text { protein }\end{array}$ & $\begin{array}{c}\text { Crude } \\
\text { fat }\end{array}$ & Ash & $\begin{array}{l}\text { Crude } \\
\text { fiber }\end{array}$ & $\begin{array}{c}\mathrm{TCA}^{22} \\
\text { precipitable N }\end{array}$ & $\begin{array}{l}\text { Amino } \\
\text { acid-N }\end{array}$ \\
\hline Casein & 9.0 & 88.2 & 0.3 & 2.0 & - & 100.0 & - \\
\hline SPI & 7.1 & 84.7 & 0.4 & 4.2 & 0.3 & 100.0 & - \\
\hline HYS & 5.3 & 84.6 & 0.6 & 3.9 & 0.5 & 9.3 & 51.5 \\
\hline DSF & 5.2 & 89.2 & 0.5 & 4.6 & 0.3 & 4.1 & 63.3 \\
\hline UDF & 3.4 & 54.9 & 13.4 & 3.9 & 2.0 & 93.9 & - \\
\hline
\end{tabular}

${ }^{1)}$ Abbreviations of $\mathrm{N}$ sources are as followes ; SPI, soybean protein isolate ; HYS, hydrolysate of SPI ; DSF, digested soluble fraction of HYS ; UDF, undigested fraction of HYS.

2) TCA, trichloroacetic acid.

Protein digests (SUgAno et al., 1988) or AA mix (YADAV and LIENER, 1977) sometimes retarded growth rate in rats when they were used as the single $\mathrm{N}$ source in the diet. Growth retardation caused by feeding diets containing suboptimal protein or those deficient in essential amino acids was frequently associated with the increase in serum cholesterol concentrations in rats (LefEver and SchneEman, 1983) and chicks (Ueda et $a l ., 1995$; UEDA and Funui, 1996). Therefore, to avoid the unexpected growth depression, in Experiment 1, SPI, HYS, DSF, UDF and AA mix simulating SPI (UEDA and FuJisAwA, 1997) as well as casein (control diet) were added to the basal diet at the N level equivalent to $5 \% \mathrm{CP}$ at the expense of glucose. In Experiment 2, the basal diet was supplemented with two levels of SPI or UDF at the expense of glucose. The added levels of SPI (6 and $12 \%$ in the diet) were equivalent to 5.1 and $10.2 \% \mathrm{CP}$, respectively, and those of UDF ( 0.6 and $1.2 \%$ in the diet) were determined according to our observation that the ratio of DSF and UDF was $9: 1$ on the weight basis.

Animals

Day-old Single Comb White Leghorn male chicks were maintained in a room with constant temperature $\left(30^{\circ} \mathrm{C}\right)$ and continuous lighting. They were raised on a commercial chick starter ration in wire-mesh cages under the restricted pre-feeding program (UEDA et al., 1995). At 7 days of age, the necessary number of chicks with similar body weight was selected from the stock. They were housed individually in metabolism cages and divided into experimental groups of eight chicks each. Chicks were given free access to experimental diets and water for 10 days. At the end of the feeding experiment, chicks were deprived of feed for $5 \mathrm{~h}$, and their body weights and feed intake were recorded. The serum and liver samples were prepared by the method previously reported (UEDA et al., 1995) to determine their cholesterol concentrations.

Chemical and statistical analyses

Trichloroacetic acid (TCA)-precipitable $\mathrm{N}$ and amino acid-N were measured by $5 \%$ TCA (Morimoto, 1971) and the formol titration method (Hirota, 1995), respectively. Cholesterol concentrations in the serum and liver were measured by enzymatic procedures as reported previously (UEDA et al., 1995). Statistical analysis was done using the analysis of variance, and comparisons among treatments were made by TukEY's 
multiple range test (YosHIDA, 1975).

\section{Results}

\section{Experiment 1}

Results are given in Table 2. Chicks given the extra $\mathrm{N}$ equivalent to $5 \% \mathrm{CP}$, regardless of the $\mathrm{N}$ sources, had a significantly higher gain/feed ratio than those fed the basal diet. They also showed a tendency to increase body weight gain, though differences were not always significant. There were no significant differences in the serum and liver cholesterol concentrations between chicks fed the basal diet (20\% CP) and those fed the control diet $(25 \% \mathrm{CP})$. When casein equivalent to $5 \% \mathrm{CP}$ in the control diet was replaced by SPI or HYS isonitrogenously, the total and LDL-cholesterol concentrations in the serum decreased to the same extent. UDF also lowered the total and LDL-cholesterol concentrations in the serum, and resultant values were significantly lower than those obtained with HYS. The total and LDL-cholesterol concentrations in the serum of chicks fed DSF and AA mix were remained unchanged. HDL-cholesterol concentrations did not differ among dietary treatments. Liver cholesterol concentrations, as compared with controls, were decreased by feeding UDF and rather increased by DSF and AA mix. SPI and HYS did not affect the liver cholesterol concentrations.

\section{Experiment 2}

Results are presented in Table 3. Body weight gain and gain/feed ratio increased linearly with the gradual addition of SPI to the basal diet, whereas they were not affected by the addition of UDF. The addition of different levels of SPI to the basal diet resulted in dose-dependent reductions in total and LDL-cholesterol concentra-

Table 2. Effects of various nitrogen $(\mathrm{N})$ sources added at the $\mathrm{N}$ level equivalent to $5 \%$ crude protein on growth performance and cholesterol concentrations in the serum and liver (Experiment 1$)^{1)}$.

\begin{tabular}{|c|c|c|c|c|c|c|}
\hline \multirow{3}{*}{ Diet $^{2)}$} & \multirow{3}{*}{$\begin{array}{c}\text { Body } \\
\text { wt gain } \\
\text { (g/10d) }\end{array}$} & \multirow{3}{*}{$\begin{array}{c}\text { Gain/feed } \\
(\mathrm{g} / 100 \mathrm{~g})\end{array}$} & \multicolumn{3}{|c|}{ Serum cholesterol } & \multirow{3}{*}{$\begin{array}{l}\text { Liver } \\
\text { cholesterol } \\
(\mathrm{mg} / \mathrm{g})\end{array}$} \\
\hline & & & Total & HDL & LDL & \\
\hline & & & \multicolumn{3}{|c|}{$(\mathrm{mg} / 100 \mathrm{ml})$} & \\
\hline Casein basal & $83.6^{\mathrm{a}}$ & $50.2^{\mathrm{a}}$ & $446^{\mathrm{e}}$ & 144 & $302^{\mathrm{d}}$ & $10.5^{\text {cde }}$ \\
\hline+ casein & $90.2^{\mathrm{ab}}$ & $55.6^{\mathrm{b}}$ & $385^{\mathrm{de}}$ & 139 & $246^{\mathrm{cd}}$ & $9.2^{\mathrm{bc}}$ \\
\hline$+\mathrm{SPI}$ & $96.8^{\mathrm{b}}$ & $57.8^{\mathrm{b}}$ & $253^{\mathrm{ab}}$ & 126 & $127^{\mathrm{ab}}$ & $8.0^{\mathrm{b}}$ \\
\hline+ HYS & $94.8^{\mathrm{b}}$ & $58.1^{\mathrm{b}}$ & $287^{\mathrm{bc}}$ & 132 & $155^{\mathrm{b}}$ & $9.4^{\mathrm{bcd}}$ \\
\hline$+\mathrm{DSF}$ & $94.0^{\mathrm{b}}$ & $56.4^{\mathrm{b}}$ & $366^{\mathrm{de}}$ & 132 & $234^{c}$ & $11.3^{\mathrm{de}}$ \\
\hline + UDF & $88.9^{\mathrm{ab}}$ & $56.1^{\mathrm{b}}$ & $203^{\mathrm{a}}$ & 127 & $76^{\mathrm{a}}$ & $4.9^{\mathrm{a}}$ \\
\hline$+\mathrm{AA} \operatorname{mix}$ & $90.6^{\mathrm{ab}}$ & $55.0^{\mathrm{b}}$ & $350^{\mathrm{cd}}$ & 124 & $226^{\mathrm{c}}$ & $12.2^{\mathrm{e}}$ \\
\hline Pooled SE & 3.0 & 1.2 & 16 & 5 & 15 & 0.5 \\
\hline $\begin{array}{l}\text { 1) Values ar } \\
\text { significantl }\end{array}$ & $\begin{array}{l}\text { neans } \mathrm{f} \\
\text { ifferent a }\end{array}$ & $\begin{array}{l}\text { eight chi } \\
<0.05\end{array}$ & each. & wi & ent & rscripts ar \\
\hline
\end{tabular}


Table 3. Effects of soybean protein isolate (SPI) and its undigested fraction (UDF) on growth performance and cholesterol concentrations in the serum and liver $(\text { Experiment } 2)^{1)}$.

\begin{tabular}{|c|c|c|c|c|c|c|}
\hline \multirow{3}{*}{ Diet } & \multirow{3}{*}{$\begin{array}{c}\text { Body } \\
\text { wt gain } \\
(\mathrm{g} / 10 \mathrm{~d})\end{array}$} & \multirow{3}{*}{$\begin{array}{c}\text { Gain/feed } \\
(\mathrm{g} / 100 \mathrm{~g})\end{array}$} & \multicolumn{3}{|c|}{ Serum cholesterol } & \multirow{3}{*}{$\begin{array}{l}\text { Liver } \\
\text { cholesterol } \\
(\mathrm{mg} / \mathrm{g})\end{array}$} \\
\hline & & & Total & HDL & $\mathrm{LDL}$ & \\
\hline & & & \multicolumn{3}{|c|}{$(\mathrm{mg} / 100 \mathrm{~m} l)$} & \\
\hline Casein basal & $90.3^{\mathrm{ab}}$ & $55.1^{b}$ & $419^{c}$ & 107 & $312^{\mathrm{c}}$ & $10.0^{\mathrm{b}}$ \\
\hline$+6.0 \% \mathrm{SPI}$ & $96.3^{\mathrm{b}}$ & $59.5^{c}$ & $245^{\mathrm{b}}$ & 95 & $150^{\mathrm{b}}$ & $7.0^{\mathrm{a}}$ \\
\hline$+12.0 \% \mathrm{SPI}$ & $109.4^{c}$ & $63.8^{\mathrm{d}}$ & $174^{\mathrm{a}}$ & 95 & $79^{\mathrm{a}}$ & $6.0^{\mathrm{a}}$ \\
\hline$+0.6 \% \mathrm{UDF}$ & $85.2^{\mathrm{a}}$ & $51.4^{\mathrm{ab}}$ & $381^{\mathrm{c}}$ & 104 & $278^{c}$ & $10.7^{\mathrm{b}}$ \\
\hline$+1.2 \% \mathrm{UDF}$ & $86.1^{\mathrm{a}}$ & $50.9^{\mathrm{a}}$ & $251^{\mathrm{b}}$ & 101 & $151^{\mathrm{b}}$ & $7.4^{\mathrm{a}}$ \\
\hline Pooled SE & 2.4 & 1.0 & 16 & 3 & 14 & 0.5 \\
\hline
\end{tabular}

1) Values are means for eight chicks each. Means with different superscripts are significantly different at $\mathrm{P}<0.05$.

tions in the serum. The addition of $1.2 \%$ UDF lowered the total and LDL-cholesterol concentrations in the serum comparable to those obtained with the addition of $6.0 \%$ SPI, whereas that of $0.6 \%$ UDF was not effective. No differences were observed in HDL-cholesterol concentrations among dietary treatments. Adding different levels of SPI to the basal diet lowered the liver cholesterol concentrations to the same extent. Liver cholesterol concentrations were not affected by adding $0.6 \%$ UDF. However, adding $1.2 \%$ UDF significantly lowered the liver cholesterol concentrations comparable to those of chicks given SPI.

\section{Discussion}

The hypercholesterolemia in chicks induced by the dietary cholesterol is prevented by the total substitution of SPI for casein (UEDA, 1992, 1997). In the present experiment, SPI was added at the $\mathrm{N}$ level equivalent to only $5 \% \mathrm{CP}$ to the casein-basal diet (CP 20\%). Even in this case, the cholesterol-lowering action of SPI as compared with casein was confirmed as shown in Table 2. However, when SPI was replaced isonitrogenously by AA mix simulating SPI, the cholesterol-lowering action of SPI disappeared as reported previously in chicks (UEDA and FUJISAWA, 1997) and other experimental animals (Huff et al., 1977 ; NAGATA et al., 1981). These results suggest that the cholesterol-lowering action of SPI is attributed to the conformation of protein rather than amino acid composition.

As shown in Table 1, the hydrolysis markedly modified the $\mathrm{N}$ distribution of SPI as characterized by the marked decrease in the TCA-precipitable $\mathrm{N}$ and the increase in amino-acid N. Nevertheless, the effects of HYS on the serum and liver cholesterol concentrations were the same as those of SPI as reported in rabbits (HufF et al., 1977). In contrast, DSF after removing UDF from HYS lost the cholesterol-lowering action (Sugano et al., 1988). Thus, UDF was expected to play an important role in the cholesterol-lowering action of SPI.

UDF certainly had a strong cholesterol-lowering action as compared with HYS in the present experiment (Table 2) as reported in rats (Sugano et al., 1988, 1990). Howev- 
er, effects of these $\mathrm{N}$ sources were compared at the isonitrogenous levels equivalent to $5 \% \mathrm{CP}$ in the present experiment or to $20 \%$ SPI in others (Sugano et al., 1988, 1990). SPI used in this study contained $10 \%$ UDF on the weight basis. Thus, $6 \%$ SPI $(5.1 \%$ as CP) consisted of $0.6 \%$ UDF and $5.4 \%$ DSF. However, the addition of $0.6 \%$ UDF $(0.33 \%$ as $\mathrm{CP})$ to the basal diet did not exert any effects on the serum and liver cholesterol concentrations in Experiment 2 (Table 3). The significant effects of UDF on the serum and liver cholesterol concentrations were obtained by doubling its supplementary level $(0.66 \%$ as $\mathrm{CP})$. Thus, UDF present in SPI was not able to account entirely for the cholesterol-lowering effect of the parent protein. This result was inconsistent with the effectiveness of HYS and ineffectiveness of DSF on the hypercholesterolemia observed in Experiment 1. This inconsistency suggests that digestion rates or digestion products are different between in vivo and in vitro ; amounts or structural features of protein digests produced in vivo are not the same as those in vitro. However, based on the fact that UDF equivalent to only $0.66 \% \mathrm{CP}$ had the same cholesterol-lowering effect as SPI equivalent to $5.1 \% \mathrm{CP}$, it is possible that UDF plays an important role in cholesterol-lowering effect of SPI.

$\mathrm{CP}$ content of UDF was lower than other $\mathrm{N}$ sources, and crude fat content was alternately higher as shown in Table 1. In addition to lipid fraction, the increase of sugar and saponin contents in UDF was also reported (Sugano et al., 1990). According to the results obtained with rats (SUgANo et al., 1990), when UDF was extracted with methanol, the hypocholesterolemic effect was partly lost. However, the methanolextracted UDF remained more effective than SPI in preventing the elevation of serum cholesterol concentrations. These results indicated that methanol-soluble fractions were not primary factor in the cholesterol-lowering effect of UDF. UDF used in this study contained about $22 \%$ unidentified fractions (analytically classified into $\mathrm{N}$-free extract). The role of these fractions in the cholesterol-lowering effect of UDF has been unclear. However, SPI itself is mostly composed of protein, and $\mathrm{N}$-free extract of SPI used in this study was $3.3 \%$. Besides, the hypocholesterolemic effect of UDF in rats disappeared with the increase in the percentage of the TCA-soluble fraction (Sugano et al., 1990). Thus, it seems unlikely that non-protein components are closely involved in the cholesterol-lowering effect of SPI.

\section{References}

De SchriJver, R. (1990) Cholesterol metabolism in mature and immature rats fed animal and plant protein. Journal of Nutrition, $120: 1624-1632$.

Hirota, N. (1995) Analytical Methods in Food Nutrients, pp. 210-213. Chikyu-sha, Tokyo. (in Japanese)

Huff, M.W., Hamilton, R.M.G. and CARroll, K.K. (1977) Plasma cholesterol levels in rabbits fed low fat, cholesterol-free, semipurified diets : Effect of dietary proteins, protein hydrolysates and amino acid mixtures. Atherosclerosis, 28 : 187-195.

IW AMI, K., SAKAKIBARA, K. and IBUKI, F. (1986) Involvement of post-digestion 'hydrophobic' peptides in plasma cholesterol-lowering effect of dietary proteins. Agricultural and Biological Chemistry, 50 : 1217-1222.

Lefever, M. and Schneeman, B. (1983) Relationship between plasma cholesterol and protein quality in weanling rats. Nutrition Reports International, $28: 1369-1374$. 
Morimoto, H. supervised. (1971) Experimental Methods in Animal Nutrition, pp. 319. Yoken-dou, Tokyo. (in Japanese)

Nagata, Y., Tanaka, K. and Sugano, M. (1981) Serum and liver cholesterol levels of rats and mice fed soy-bean protein or casein. Journal of Nutritional Science and Vitaminology, 27 : 583-593.

Sugano, M., Goto S., Yamada, Y., Yoshida, K., Hashimoto, Y., Matsuo, T. and Kimoto, M. (1990) Cholesterol-lowering activity of various undigested fraction of soybean protein in rats. Journal of Nutrition, 120 : 977-985.

Sugano, M., Ishiwaki, N. and NAKashima, K. (1984) Dietary protein-dependent modification of serum cholesterol level in rats. Significance of the arginine/lysine ratio. Annals of Nutrition and Metabolism, $28: 192-199$.

Sugano, M., Yamada, Y., Yoshida, K., Hashimoto, Y., Matsuo, T. and Kimoto, M. (1988) The hypocholesterolemic action of undigested fraction of soybean protein in rats. Atherosclerosis, $72: 115-122$.

Sugiyama, K., Mizuno, M. and Muramatsu, K. (1986a) Effect of individual amino acids on plasma cholesterol level in rats fed a high cholesterol diet. Journal of Nutritional Science and Vitaminology, $32: 623-633$.

SugiYama, K., OhKawA, S. and Muramatsu, K. (1986 b) Relationship between amino acid composition of diet and plasma cholesterol level in growing rats fed a high cholesterol diet. Journal of Nutritional Science and Vitaminology, $32: 413-423$.

UEDA, H. (1992) Effects of dietary protein and soybean saponins on plasma cholesterol concentration in chicks. Animal Science and Technology, $63: 793-799$.

UEDA, H. (1997) Effects of 18 amino acids individually added to the diet containing casein or soybean protein isolate on the serum cholesterol concentrations in chicks. Animal Science and Technology, $68: 926-933$.

Ueda, H. and Fujisawa, Y. (1997) Partial substitution of amino acid mixture for soybean protein isolate or casein modifies the effects on serum and liver cholesterol concentrations in chicks. Animal Science and Technology, 68 : 1032-1038.

UEDA, H. and Fukui, W. (1996) Effects of methionine and cystine on the cholesterol concentrations in the serum and liver of cholesterol-fed chicks. Animal Science and Technology, $67: 533-540$.

Ueda, H., ImANiShi, T., FukUmi, R. and Kumai, S. (1995) Effect of dietary lysine and arginine addition on growth performance and serum cholesterol level in chicks. Animal Science and Technology, $66: 412-421$.

UEDA, H. and Shigemizu, G. (1998) Effects of tea saponin, cholesterol and oils on the growth and feed passage rate in chicks. Animal Science and Technology, $69: 14-21$.

VAN der MEER, R. and BEynen, A.C. (1987) Species-dependent responsiveness of serum cholesterol to dietary proteins. Journal of American Oil Chemists' Society, $64: 1172-1177$.

YADAV, N.R. and LIENER, L.E. (1977) Reduction of serum cholesterol in rats fed vegetable protein or an equivalent amino acid mixture. Nutrition Reports International, 16 : 385-389.

YoshidA, M. (1975) Design of Experiments for Animal Husbandry, pp. 125-162. Yoken-dou, Tokyo. (in Japanese) 


\title{
分離大豆タンパク質の微生物プロテアーゼ不消化画分がニワトリヒ ナの血清および肝茞コレステロール濃度に及ぼす影響
}

\author{
上田博史・黒木知子
}

愛媛大学農学部, 松山市樽味 790-8566

分離大豆タンパク質（SPI）および微生物プロテアー ゼで処理した SPIの種々の画分を 7 日歯命のニワトリヒ ナに 10 日間給与し，血清および肝臓コレステロール濃 度に及ぼす影響を調べた。カゼインをタンパク質源とす る粗タンパク質含量（CP） $20 \%$ の半精製飼料に $0.5 \%$ の コレステロールを添加し, 基礎飼料とした。試験 1 では, 6 種類の窒素源をそれぞれ CP 5\% になるように基礎飼 料に添加した。SPI およびSPIをプロテアーゼ処理した 加水分解物は, カゼインと比較して, 血清および肝臓コ レステロール濃度を有意に低下させた。しかし，加水分 解物から不消化部を除いた可溶部, および SPI と同じア ミノ酸組成をもつアミノ酸混合物にはコレステロール降 下作用がみられなかった。これに対し，不消化部は等窒 素の加水分解物より強いコレステロール降下作用を示し

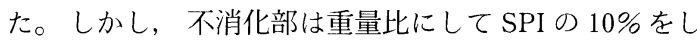
めるにすぎない。そこで試験 2 では，6\%および $12 \%$ SPI（CP $5.1 \%$ および $10.2 \%$ に相当）中に存在する不消 化部 $(0.6 \%$ および $1.2 \%)$ を基礎飼料に添加し，コレス テロール降下作用を SPI と比較した。その結果, $0.6 \%$ の 不消化部の添加は血清および肝臓コレステロール濃度に 影響を与えず， $6 \%$ SPI 添加によるコレステロール降下 作用之同程度の効果を得るには, $1.2 \%$ の不消化部を必 要とした。したがって, SPIのコレステロール降下作用 は不消化部だけでは説明できないが，不消化部が強いコ レステロール降下作用をむつことが明らかになった。

（家禽会誌, $37: 19-26,2000$ ) キーワード: 大豆タンパク質, 加水分解物, 不消化部, コレステロール 